\title{
A new trigonotarbid arachnid from the Coal Measures of Hagen-Vorhalle, Germany
}

\author{
Jason A. Dunlop ${ }^{*, 1}$ \& Carsten Brauckmann ${ }^{* *, 2}$ \\ ${ }^{1}$ Museum für Naturkunde der Humboldt-Universität zu Berlin, Invalidenstraße 43, D-10115 Berlin, Germany \\ 2 Institut für Geologie und Paläontologie, Technische Universität Clausthal, Leibnizstraße 10, D-38678 Clausthal-Zellerfeld, \\ Germany
}

Received 7 August 2005, accepted 20 September 2005

Published online 01. 02. 2006

With 3 figures

Key words: Carboniferous, Namurian, Trigonotarbida, Trigonotarbidae, Archaeomartus, new species.

\begin{abstract}
A new trigonotarbid (Arachnida: Trigonotarbida: Trigonotarbidae) is described as Archaeomartus roessleri n. sp. from the Upper Carboniferous (Pennsylvanian; Namurian B, higher Marsdenian) of Hagen-Vorhalle, Germany. Originally assigned to Trigonotarbus johnsoni Pocock, 1911, our new fossil has a distinctly lobed carapace and thus resembles more closely the Early Devonian species Archaeomartus levis Størmer, 1970. In carapace morphology Archaeomartus approaches the condition seen in the larger and more heavily-armoured taxa Eophrynidae, Kreischeriidae and Aphantomartidae. Thus we provisionally resolve Archaeomartus as sister-group to this probably monophyletic trio of families and discuss the possibility that Trigonotarbidae may be paraphyletic.
\end{abstract}

Schlüsselwörter: Karbon, Namurium, Trigonotarbida, Trigonotarbidae, Archaeomartus, neue Art.

\section{Zusammenfassung}

Ein neuer Trigonotarbiden-Fund (Arachnida: Trigonotarbida: Trigonotarbidae) aus dem Ober-Karbon (Pennsylvanium; Namurium B, höheres Marsdenium) von Hagen-Vorhalle, Deutschland, wird als Archaeomartus roessleri n. sp. beschrieben. Bei der Erst-Dokumentation wurde er noch zu Trigonotarbus johnsoni Pocock, 1911 gestellt; er unterscheidet sich hiervon aber durch die deutlichen Loben auf dem Carapax und ähnelt damit eher dem unterdevonischen Archaeomartus levis Størmer, 1970. In der Carapax-Morphologie nähert sich Archaeomartus mehr den größeren und kräftiger skulptierten Eophrynidae, Kreischeriidae und Aphantomartidae. Daher fassen wir Archaeomartus zumindest vorläufig als Schwestergruppe dieser wahrscheinlich monophyletischen Familien-Dreiergruppe auf; die Trigonotarbidae könnten somit paraphyletisch sein.

(C) 2006 WILEY-VCH Verlag GmbH \& Co. KGaA, Weinheim

\section{Introduction}

Trigonotarbids (Arachnida: Trigonotarbida) are an extinct order of arachnids which are currently known from the late Silurian (Př́ídolí: ca. $414 \mathrm{Ma}$ ) to the early Permian (Asselian: ca. 290 Ma) (Dunlop 1996a; Rössler 1998; Rössler et al. 2003). They have been recovered most frequently from the Upper Carboniferous of Europe and North America where they are often one of the more abundant fossil arachnid groups found in these Coal Measures ecosystems. They are far more frequent than spiders for example in these assemblages. Around fifty trigonotarbid species have been described in total, although this is probably an over-estimate since revisions

\footnotetext{
* Corresponding author: e-mail: jason.dunlop@museum.hu-berlin.de

** E-mail: carsten.brauckmann@tu-clausthal.de
} 
have usually resulted in numerous synonyms (e.g. Rössler 1998). Trigonotarbids resemble spiders, but lack silk-producing spinnerets. Trigonotarbids have a characteristic morphology of opisthosomal tergites divided into median and lateral plates. This they share with the rare Carboniferous-Recent Ricinulei, and the two orders have in some schemes been resolved as sistertaxa (Dunlop 1996b; Giribet et al. 2002), basal to the so-called tetrapulmonate arachnids; i.e. a phylogeny of the form: ((Trigonotarbida + Ricinulei) + (Araneae (Amblypygi (Uropygi + Schizomida)))). The extinct trigonotarbids almost certainly fed on other arthropods and probably either ran down or ambushed their prey. Well-preserved Devonian examples have mouthparts which strongly indicate that they were predatory, that they were not venomous and that they digested their food pre-orally like many modern arachnids (Shear et al. 1987; Dunlop 1994a).

The majority of the described Carboniferous trigonotarbids were found at classic Westphalian localities like the Saarland of Germany, the British Middle Coal Measures, Mazon Creek in the USA and Nýřany in the Czech Republic. In recent years a number of well-preserved fossil arachnids have been recovered from slightly older (Namurian) sediments found in a former brickyard quarry at Hagen-Vorhalle in the Ruhr area of Germany (Brauckmann 1987a, 1991; Brauckmann et al. 1985, 2003). These included a new trigonotarbid species, Eophrynus udus Brauckmann in Brauckmann et al., 1985, an unnamed, incomplete trigonotarbid (Brauckmann 1987a) and most recently (Brauckmann et al. 2003; Brauckmann \& Schöllmann 2005) trigonotarbid material provisionally assigned to the British species Trigonotarbus johnsoni Pocock, 1911 (Trigonotarbidae). Re-examination of the last specimen revealed that, unlike $T$. johnsoni, it has a carapace with lateral lobes - more like that of the Early Devonian species Archaeomartus levis Størmer, 1970 (see description by Brauckmann 1987b). The Hagen-Vorhalle fossil is thus reinterpreted as a new species of Archaeomartus Størmer, 1970 which we describe here.

\section{Material}

The holotype (P21 046) and only known specimen was obtained from its repository in the Westfälisches Museum für Naturkunde (WMfN), Münster, Germany. Drawings were prepared using a Leica MZ 12 stereomicroscope with a drawing tube attachment. Pocock's type and figured material of
Trigonotarbus johnsoni from the British Middle Coal Measures (Westphalian B) of Coseley, Staffordshire, UK, was examined, drawn and photographed some years ago by JAD in the Natural History Museum, London (NHM).

\section{Geological setting}

The Hagen-Vorhalle locality in the German state of North Rhine-Westphalia is an internationally significant locality for Coal Measures fauna and flora. The most productive horizon for fossils are the so called "Vorhalle-Schichten" which have been dated as Upper Carboniferous, Namurian B (higher Marsdenian) based on goniatite stratigraphy. Hagen-Vorhalle is situated on the site of a former brickworks and the fossils were intensively collected between 1990 and 1997 by the "Paläontologische Bodendenkmalpflege" of the Westphalian Museum of Natural History. Part of the locality is now registered as a protected geological site for the town of Hagen. In addition to many plants, more than 300 fossils of terrestrial arthropods are known from museum and private collections. The Hagen-Vorhalle locality has yielded a diverse range of eighteen insect species, six arachnids (including the new species described here) and among the aquatic faunal component, some incomplete eurypterids. A summary and further background literature can be found in Brauckmann et al. (2003) and Hendricks (2005).

\section{Morphological interpretation}

The new fossil (Figs 1,2) is an almost complete specimen preserved essentially in dorsal view

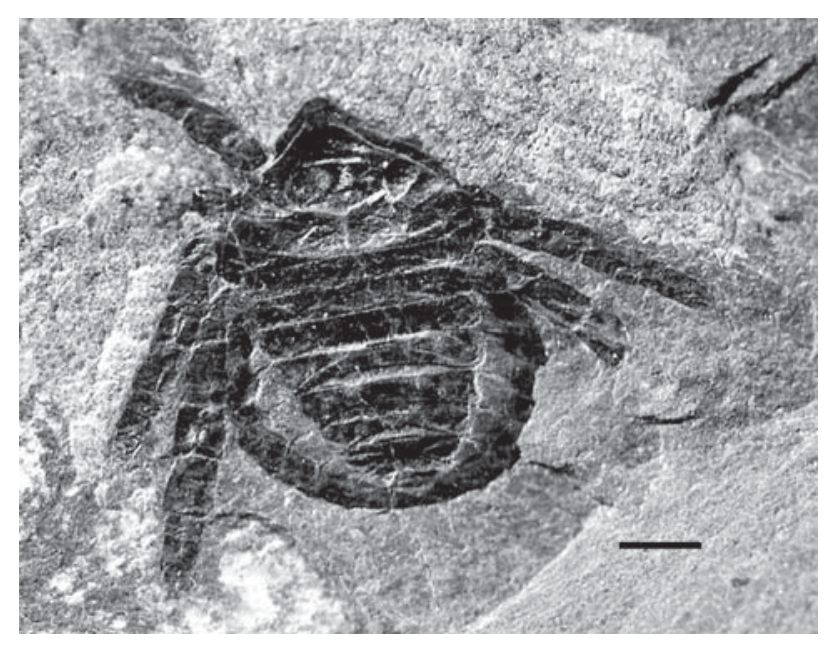

Fig. 1. Holotype and only known specimen (WMfN P21 046) of Archaeomartus roessleri n. sp. from Upper Carboniferous (Namurian B, late Marsdenian) Coal Measures of HagenVorhalle, Germany. 


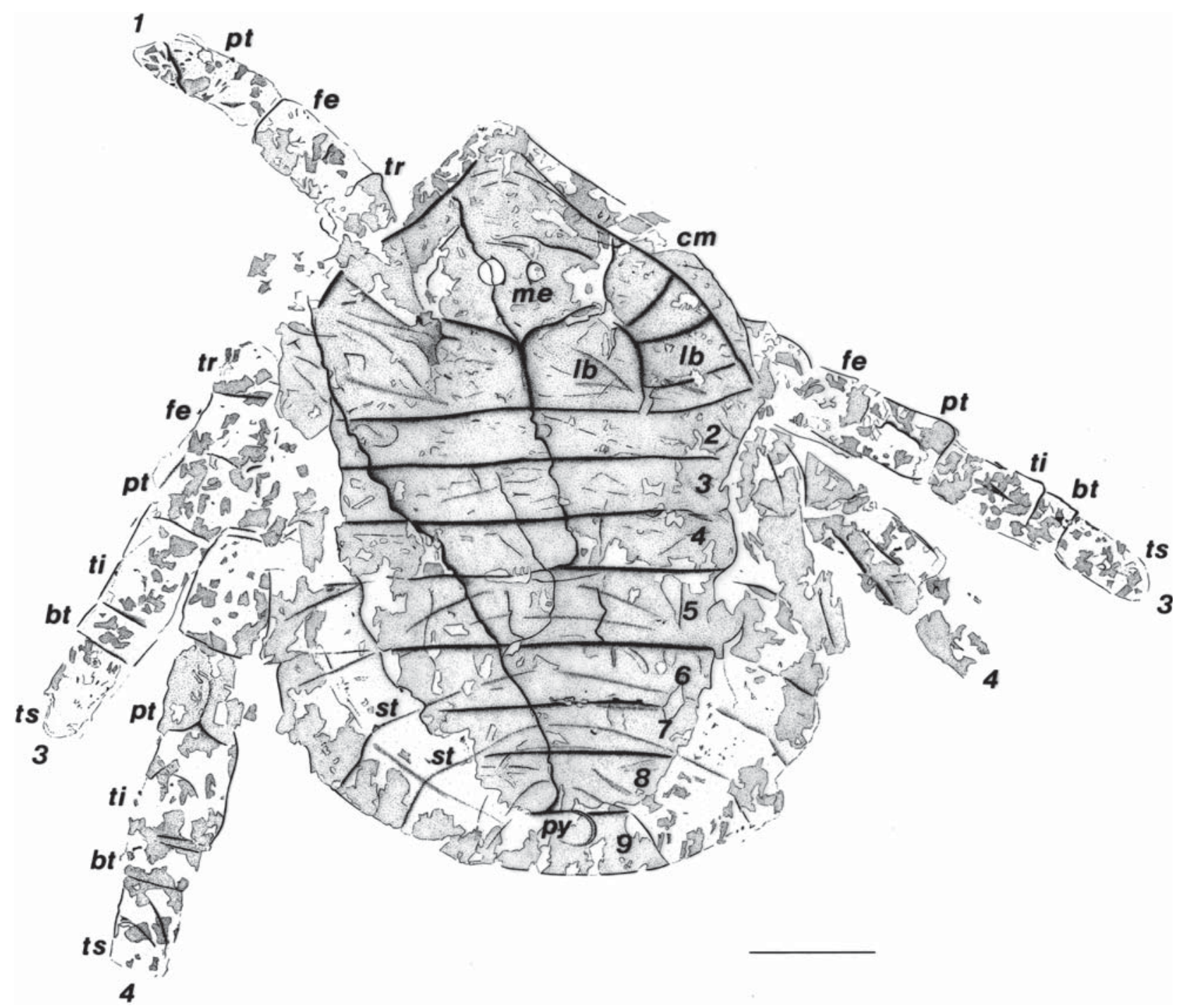

Fig. 2. Camera lucida drawing of the specimen shown in Fig. 1. Abbreviations: bt, basitarsus; cm, carapace margin; fe, femur; lb, carapace lobe; me, median eyes; pt, patella; py, superimposed pygidium; st, superimposed sternite boundaries; ti, tibia; tr, trochanter; ts tarsus. Opisthosomal tergites numbered from 2-9, legs from 1-4; see text for details. Scale bar equals $1 \mathrm{~mm}$.

with a body length of about $6 \mathrm{~mm}$. Under $70 \%$ ethanol areas of original cuticle are revealed as darker patches and this area of preserved cuticle is concentrated on the central region of the body, becoming more fragmentary at the margins of the opisthosoma and on the legs. Although compressed in a shale, some three-dimensionality (especially of the carapace and between adjacent tergites) is retained and surface relief is best revealed under low-angle lighting. Two sets of cracks run through the specimen, one close to the midline, another at an oblique angle across the left side. They do not seriously obscure the morphology of the specimen. A reconstruction of its probable appearance in life is given in Fig. 3 and suggests that this was a squat, robust little animal with short, rather heavily built legs.

We cannot, however, completely rule out the possibility that the fossil has undergone some de- gree of tectonic deformation, foreshortening the body and legs for example. Such deformation can occur at Hagen Vorhalle - see e.g. Brauckmann (1991, pl. 13: fig. 12) in which the wings of the insect figured here differ in length within a single specimen - but we have only a single example of our new arachnid and unfortunately no reference point, such as a plant or ammonoid in the same slab, which would allow us to assess the degree of any deformation which had occurred.

Carapace - The carapace of the new fossil is subtriangular, wider than long, and bluntly rounded at the front. The carapace bears a single pair of median eyes at its highest point. These lack preserved cuticle in the fossil and are set into slight recesses or sockets just in front of the central point of the carapace. The whole median 
region of the carapace is raised - the 'glabella' sensu Brauckmann 1987b - and forms three distinct lobes, the anteriormost of which bears the eyes. The two lobes behind this are divided from the anterior lobe, and each other, by strong suture lines. Either side of this raised, central region the lateral flanks of the carapace exhibit a series of procurved folds or suture lines defining three subrectangular to subtriangular lobes on each side. This fossil bears smooth and strongly demarcated lateral carapace margins which were probably slightly raised in life. This closely resembles the condition seen in Lissomartus schucherti (Petrunkevitch, 1913); see illustrations in Dunlop (1995a). The posterior margin of the carapace in our new fossil is straight, not raised, and further ornament in the form of spines or tubercles on the carapace is lacking.

Appendages - The coxo-sternal region, mouthparts and pedipalps in our new fossil are equivocal. Although cuticle preservation is patchy, boundaries of leg articles can be resolved under low-angle lighting. Leg 1 is known only from the proximal articles which seem to indicate a femur and patella of about the same length. Leg 2 is missing, but legs 3 and 4 are essentially complete. In general the legs are noticeably short and stubby with rather wide articles compared to other known Carboniferous trigonotarbids (e.g. Dunlop 1995a). Articles appear to have been basically cylindrical, but a slight distal

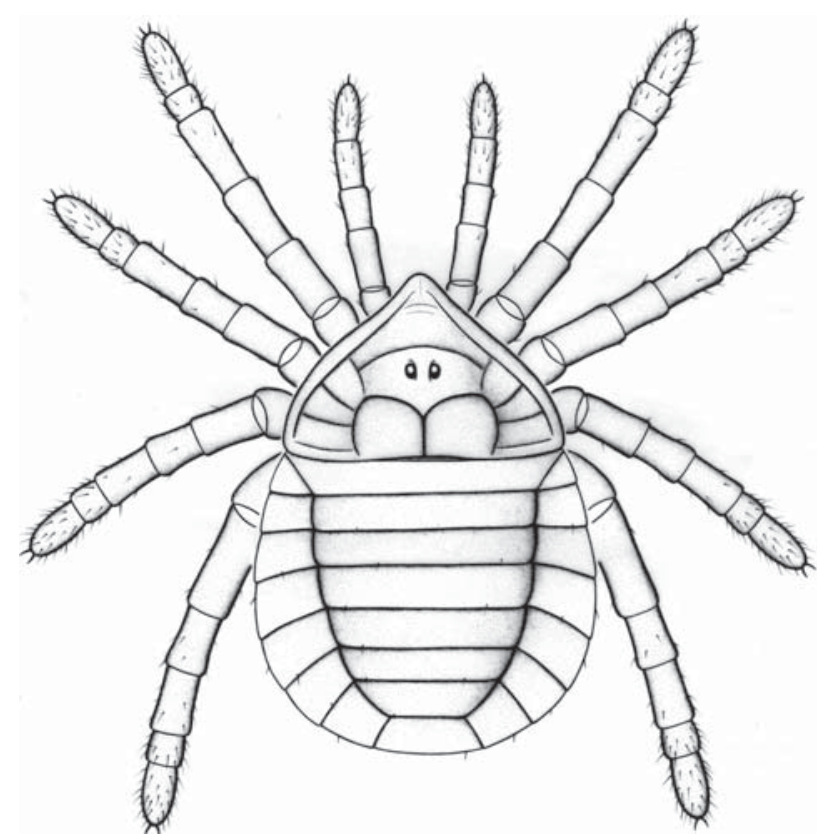

Fig. 3. Sketch reconstruction of the probable appearance of Archaeomartus roessleri $\mathrm{n}$. $\mathrm{sp}$. in life. Setae and other details based on better preserved Devonian trigonotarbids and comparisons with extant arachnids. widening of both the patella and tibia can be detected. In legs 3 and 4 the femur, tibia and tarsus are the longest articles, the patella is shorter, while the very short basitarsus (or metatarsus) is reminiscent of early derivative trigonotarbids like palaeocharinids; see e.g. illustrations in Dunlop (1996b) and Fayers et al. (2005). The tarsus in our fossil is bluntly rounded distally. A pair of tarsal claws would be predicted (see Fig. 3) from better preserved Devonian material (e.g. Shear et al. 1987), but are not seen here.

Opisthosoma - The opisthosoma in the new fossil is rounded and, unusually for trigonotarbids, slightly wider than long. Tergites are strongly differentiated from each other along the length of the opisthosoma and have straight margins in the median region. However, the characteristic trigonotarbid division into median and lateral plates is weakly expressed and best defined by cuticle distribution which seems to be more or less complete on the median plates only (Fig. 2). The inner region of the lateral plates is thus outlined by wide gaps in the preserved cuticle on both sides of the opisthosoma, with further (tergal) cuticle fragments reappearing at the margins. Unlike the median plates, divisions between the lateral plates are poorly defined and interpretations are complicated by the superimposition of ventral elements onto the dorsal surface. This is a typical feature of trigonotarbids compressed in shales. Here, the outline of the ventral sternites can be seen towards the back and sides of the opisthosoma - presumably because the animal was thinner here in life. Traces of up to five sternites are visible in our fossil. Unlike the tergites, these are all somewhat procurved, more rounded elements, with the degree of curvature increasing posteriorly. The posteriormost sternite surrounds another typical trigonotarbid feature, a ventral pygidium (or postabdomen) formed from two small, circular segments which are also impressed here through onto the dorsal surface. This pygidium represents either opisthosomal segments 10-11 (Shear et al. 1987) or 11-12 (Dunlop 1996b) and probably bore the anal opening in life.

Eight clear tergal elements are preserved in the fossil; however, assigning tergites unequivocally to segments in trigonotarbids is challenging. Petrunkevitch (1949), for instance, claimed (probably incorrectly) that segment number was variable within Trigonotarbida. Studies of wellpreserved Devonian material (Shear et al. 1987; Dunlop 1996b; Fayers et al. 2005) revealed that 
the first tergite in trigonotarbids is usually a modified into a so-called locking ridge which tucked into a fold at the back of the carapace and thus 'locked' the prosoma and opisthosoma together. Something similar is present in extant ricinuleids. This first tergite seems to become reduced in more derived trigonotarbids (Dunlop $1994 \mathrm{~b}$ ), thus it is rarely detected in Carboniferous material - the present fossil included - because it is either: (a) hidden beneath the carapace and/or (b) reduced in size. Thus the first tergite visible in our fossil is recognised as tergite 2.

Furthermore, some trigonotarbids have the second and third tergites fused together into a diplotergite $(2+3)$ (e.g. Shear et al. 1987; Dunlop 1996b; Fayers et al. 2005). This condition is usually easily recognisable as a noticeably larger tergite at the front of the opisthosoma. This is not the case in our fossil, in which the anteriormost tergites are all approximately the same length. For this reason we suspect that tergal fusion - which is probably homoplastic for Trigonotarbida (see e.g. Dunlop 1995b for further examples of unfused tergites) - is not present in our fossil and we can simply number the eight tergites present as 2-9. This fits studies of other trigonotarbids in which the posteriormost tergite is invariably the ninth. This tergite 9 is divided in some taxa, undivided in others. Shear (2000) discussed the polarity and significance of this character. In our fossil the ninth tergite appears to be undivided.

\section{Discussion}

There is a lineage of trigonotarbids with subtriangular carapaces, beginning with the oldest known (Silurian) species (Dunlop 1996a). By contrast, other trigonotarbids have more quadrate or rounded carapaces and, in some species, these retain an additional pair of lateral eye tubercles (Shear et al. 1987; Fayers et al. 2005); almost certainly the plesiomorphic character state. The 'triangular-carapace' trigonotarbids, which have lost their lateral eyes, may represent a derived (monophyletic) lineage. Provisionally, this group comprises the Silurian plesion genus and the families Trigonotarbidae (including our new species), Lissomartidae, Eophrynidae, Kreischeriidae and Aphantomartidae; although in the last the carapace seems to have reversed to a less triangular outline (see e.g. figures in Rössler 1998). Details of lissomartid, eophrynid and kreischeriid morphology can be found in the redescriptions of Dunlop (1995a, b) and Rössler \& Dunlop (1997) respectively.

Evolutionary trends - Within this suite of taxa we can detect an evolutionary trend towards increased structural complexity in the carapace. This is reflected in the appearance of a raised, central carapace region, present in Trigonotarbus Pocock, 1911 (Trigonotarbidae) and Lissomartus Petrunkevitch, 1949 (Lissomartidae). The next stage seems to have been the appearance of subtriangular lateral lobes flanking this central carapace region. The earliest stages of this were documented by Dunlop (1995a, figs 3, 7) in Lissomartus, where there are faint lateral divisions on the flanks of the carapace. At a more derived grade, these carapace lobes on the flanks appear to have become more strongly defined. Exactly this stage of organisation is reflected in the Alken species, Archaeomartus levis (Trigonotarbidae), as figured by Brauckmann (1987b, figs 3-4), and our new Hagen-Vorhalle fossil (Figs 1-3), which we consequently assign to the same genus (see Systematic Palaeontology). Provisionally, the next level of organisation - perhaps deriving from the Archaeomartus condition - would be the appearance of larger, much more heavily ornamented animals with dense pustules or tubercles covering the carapace and dorsal opisthosoma. Such ornamentation is characteristic for the eophrynid-kreischeriid-aphantomartid group (which we here term the 'eophrynid assemblage'), and could well be synapomorphic for them.

\section{Systematic palaeontology}

Order Trigonotarbida Petrunkevitch, 1949 Family ? Trigonotarbidae Petrunkevitch, 1949

Remarks. Trigonotarbidae currently comprises two genera: Trigonotarbus and Archaeomartus. However, since a strongly lobed carapace occurs only in Archaeomartus and the 'eophrynid assemblage' (see above), we must entertain the possibility that Trigonotarbidae is paraphyletic. Archaeomartus could be sister-group to the 'eophrynid assemblage' based on the synapomorphy of a strongly lobed carapace. Yet the first stages of lobation occur in Lissomartus, a genus which also shares some features with our new Archaeomartus species, like the strongly defined carapace margin. In terms of the degree of lobation, Lis- 
somartus also seems to be intermediate between Trigonotarbus and Archaeomartus. Clearly, more work is required to resolve relationships among these genera, but a phylogeny of the form (Trigonotarbus (Lissomartus (Archaeomartus + 'eophrynids'))) is conceivable based on carapace characters; which would render Trigonotarbidae paraphyletic. Indeed the unpublished thesis of Dunlop (1994b) proposed raising $A r$ chaeomartus to a new family; albeit for slightly different reasons to those outlined here. We prefer not to create monogeneric families at this stage pending careful restudy of the three species currently assigned to Trigonotarbus (cf. Pocock 1911; Petrunkevitch 1955; Schultka 1991) and a more thorough cladistic analysis of Trigonotarbida.

\section{Archaeomartus Størmer, 1970.}

Type species. Archaeomartus levis Størmer, 1970 (by original designation).

Additional species. Archaeomartus tuberculatus Størmer, 1970, Archaeomartus roessleri $\mathrm{n}$. sp.

Diagnosis. Trigonotarbidae with a lobed, subtriangular carapace and rounded opisthosoma, wider than long; body lacking spines, dense tuberculation or other strong ornament (emended from Brauckmann 1987b).

Remarks. Archaeomartus was originally raised by Størmer (1970) for two species from the Early Devonian of Alken an der Mosel, both described from isolated, rounded opisthosomas and differentiated from each other by the presence or absence of marginal tuberculation. Brauckmann (1987b) described a more complete specimen of $A$. levis which included for the first time the carapace, which was found to have a distinctly lobed morphology. This material also confirmed that the opisthosoma is slightly wider than long in A. levis which matches our new fossil, although as noted above further specimens may be needed to exclude the possibility that this is due to deformation in the Hagen Vorhalle material. In its carapace lobation and (perhaps) opisthosomal proportions our new species matches $A$. levis, and can be excluded from the type species of Trigonotarbidae, Trigonotarbus johnsoni, to which it was originally referred (Brauckmann et al. 2003; Brauckmann \& Schöllmann 2005). T. johnsoni has smooth marginal carapace regions, a large diamond-shaped depression in the back of the carapace and a more circular opisthosoma; see e.g. figures in Pocock
(1911) and Petrunkevitch (1949). Based on similarities with $A$. levis, we refer our new fossil to Archaeomartus as redefined above.

\section{Archaeomartus roessleri n. sp.}

Figs 1-3.

2003 Trigonotarbus johnsoni - Brauckmann et al.: 48, textfig. 19, pl. 10., fig. 1. (misidentification)

2005 Trigonotarbus johnsoni - Brauckmann \& Schöllmann: 71, fig. 2. (misidentification)

Dervation of name. For our colleague Dr Ronny Rössler (Chemnitz), in recognition of his work on trigonotarbids and late Palaeozoic terrestrial ecosystems in general.

Holotype and only specimen. WMfN P21 046; almost complete specimen in dorsal view.

Diagnosis. Archaeomartus with three lobes forming the central carapace region, divided from each other by a Yshaped suture; legs relatively short, leg length about equal to or less than the width of the opisthosoma.

Type locality. Hagen-Vorhalle, Germany.

Type-horizon. Vorhalle beds, goniatite subzone R2c, Upper Carboniferous (Pennsylvanian), Namurian B, late Marsdenian (ca. $319 \mathrm{Ma}$ ).

Description. Body squat and compact, lacking spines, tubercles or other ornament. Total length ca. $6 \mathrm{~mm}$. Carapace subtriangular, wider than long, bluntly rounded anteriorly and with broad, strongly demarcated lateral margins. Length $2.3 \mathrm{~mm}$, maximum width ca. $4 \mathrm{~mm}$. Median area of carapace raised and divided into three principal lobes. Anteriormost lobe bears a single pair of median eyes, each located in a slightly depressed socket. Behind this front lobe, a further pair of lobes occur, strongly demarcated from the anterior lobe and from each other by a Yshaped depression. Lateral carapace regions between the median area and the broad margin divided on each side into three rectangular to subtriangular lobes, outlined by slightly procurving sutures. Posterior margin of carapace straight. All legs short and robust with thick, stubby articles. Patella and tibia widening slightly distally. Basitarsus short, cylindrical. Tarsus bluntly rounded distally. Individual article lengths as follows. Leg 3: femur 0.7, patella 0.6 , tibia 0.8 , basitarsus 0.3 , tarsus $0.8 \mathrm{~mm}$. Leg 4: femur 1.2, patella 0.7 , tibia 0.9 , basitarsus 0.3 , tarsus at least $0.7 \mathrm{~mm}$. Opisthosoma rounded, slightly wider than long. Length $3.7 \mathrm{~mm}$, maximum width $4.5 \mathrm{~mm}$. Median tergites decreasing successively in width posteriorly; lateral tergites preserved as fragments only. Posterior margins of all median tergites straight. Eight tergites, probably representing segments 2-9, visible. Approximate lengths: $2: 0.4,3: 0.5,4: 0.4,5: 0.6,6: 0.5,7: 0.4,8$ : 
0.5 and 9: $0.4 \mathrm{~mm}$. Margins of five ventral sternites and two segments constituting the small, circular pygidium, diameter ca. $0.3 \mathrm{~mm}$. Sternites procurved, especially posteriorly around pygidium.

\section{Acknowledgements}

We thank Lothar Schöllmann (WMfN) and Andrew Ross (NHM) for access to material in their care, Mrs G. Thomas (WMfN) for preparing Fig. 1 and Paul Selden (Manchester) and Ronny Rößler (Chemnitz) for helpful comments during review.

\section{References}

Brauckmann, C. 1987a. Neue Arachniden (Ricinuleida, Trigonotarbida) aus dem Namurium B von Hagen-Vorhalle (Ober-Karbon, West-Deutschland). - Dortmunder Beiträge zur Landeskunde, Naturwissenschaftliche Mitteilungen 20: 97-109.

- 1987b. Neue Arachniden-Funde (Scorpionida, Trigonotarbida) aus dem westdeutschen Unter-Devon. - Geologica et Palaeontologica 21: 73-85.

- 1991. Arachniden und Insekten aus dem Namurium von Hagen-Vorhalle (Ober-Karbon; West-Deutschland). Veröffentlichungen aus dem Fuhlrott-Museum 1: 1-275.

Brauckmann, C., Koch, L. \& Kemper, M. 1985. Spinnentiere (Arachnida) und Insekten aus den Vorhalle-Schichten (Namurium B; Ober-Karbon) von Hagen-Vorhalle (WestDeutschland). - Geologie und Paläontologie in Westfalen 3: $1-131$.

Brauckmann, C. \& Schöllmann, L. 2005. Arachnida (Spinnentiere). - In Hendricks, A. (ed.): Als Hagen am Äquator lag. Die Fossilien der Ziegeleigrube Hagen-Vorhalle: 70-75, Landschaftsverband Westfalen-Lippe, Westfälisches Museum für Naturkunde.

Brauckmann, C., Schöllmann, L. \& Sippel, W. 2003. Die fossilen Insekten, Spinnentiere und Eurypteriden von Hagen-Vorhalle. - Geologie und Paläontologie in Westfalen 59: $1-89$.

Dunlop, J. A. 1994a. Filtration mechanisms in the mouthparts of tetrapulmonate arachnids (Trigonotarbida, Araneae, Amblypygi, Uropygi, Schizomida). - Bulletin of the British arachnological Society 9: 267-273.

- 1994b. Palaeobiology of the trigonotarbid arachnids. Unpublished Ph.D. thesis, University of Manchester, UK, $512 \mathrm{pp}$.

- 1995a. Redescription of the Pennsylvanian trigonotarbid arachnid Lissomartus Petrunkevitch, 1949 from Mazon Creek, Illinois. - Journal of Arachnology 23: 118-124.

- 1995b. A redescription of two eophrynids (Arachnida: Trigonotarbida) from the Coal Measures (Carboniferous) of Ostrava, Czech Republic. - Neues Jahrbuch für Geologie und Paläontologie, Monatshefte 1995 (8): 449-461.
- 1996a. A trigonotarbid arachnid from the Upper Silurian of Shropshire. - Palaeontology 39: 605-614.

- 1996b. Evidence for a sister group relationship between Ricinulei and Trigonotarbida. - Bulletin of the British arachnological Society 10: 193-204.

Fayers, S. R., Dunlop, J. A. \& Trewin, N. H. 2005. A new early Devonian trigonotarbid arachnid from the Windyfield chert, Rhynie, Scotland. - Journal of Systematic Palaeontology 2: 269-284.

Giribet, G., Edgecombe, G. D., Wheeler, W. C. \& Babbitt, C. 2002. Phylogeny and systematic position of Opiliones: a combined analysis of chelicerate relationships using morphological and molecular data. - Cladistics 18: 5-70.

Hendricks, A. (ed.) 2005. Als Hagen am Äquator lag. Die Fossilien der Ziegeleigrube Hagen-Vorhalle. 222 pp., Landschaftsverband Westfalen-Lippe, Westfälisches Museum für Naturkunde, Münster.

Petrunkevitch, A. I. 1913. A monograph of the terrestrial Palaeozoic Arachnida of North America. - Transactions of the Connecticut Academy of Arts and Science 18: 1-137.

- 1949. A study of Palaeozoic Arachnida. - Transactions of the Connecticut Academy of Arts and Science 37: 69315.

- 1955. Trigonotarbus arnoldi, a new species of fossil arachnid from Southern France. - Journal of Paleontology 29: $475-477$.

Pocock, R. I. 1911. A monograph of the terrestrial Carboniferous Arachnida of Great Britain. - Monographs of the Palaeontographical Socieity, $84 \mathrm{pp}$.

Rössler, R. 1998. Arachniden-Neufunde im mitteleuropäischen Unterkarbon bis Perm - Beitrag zur Revision der Familie Aphantomartidae Petrunkevitch 1945 (Arachnida, Trigonotarbida). - Paläontologische Zeitschrift 72: 67-88.

Rössler, R. \& Dunlop, J. A. 1997. Redescription of the largest trigonotarbid arachnid - Kreischeria wiedei Geinitz 1882 from the Upper Carboniferous of Zwickau, Germany. - Paläontologische Zeitschrift 71: 237-245.

Rössler, R., Dunlop, J. A. \& Schneider, J. W. 2003. A redescription of some poorly known Rotliegend arachnids from the Lower Permian (Asselian) of the Ilfeld und Thuringian Forest Basins, Germany. - Paläontologische Zeitschrift 77: 417-427.

Schultka, S. 1991. Trigonotarbus stoermeri n. sp. - ein Spinnentier aus den Bensberger Schichten (Ems/Unter-Devon) des Rheinischen Schiefergebirges. - Neues Jahrbuch für Geologie und Paläontologie, Abhandlungen 183: 375 390.

Shear, W. A. 2000. Gigantocharinus szatmaryi, a new trigonotarbid arachnid from the Late Devonian of North America (Chelicerata, Arachnida, Trigonotarbida). - Journal of Paleontology 74: 25-31.

Shear, W. A., Selden, P. A., Rolfe, W. D. I., Bonamo, P. M. \& Grierson, J. D. 1987. New terrestrial arachnids from the Devonian of Gilboa, New York (Arachnida, Trigonotarbida). American Museum Novitates 2901: 1-74.

Størmer, L. 1970. Arthropods from the Lower Devonian (Lower Emsian) of Alken an der Mosel, Germany. Part 1: Arachnida. - Senckenbergiana lethaea 51: 335-369 